\title{
Searching for a Way Out of the Labyrinth of Digital Financial Innovations - The Trap of Regulatory Challenges in the Digital Financial System*
}

\author{
János Müller - Ádám Kerényi
}

We are monitoring the regulatory tasks and needs in relation to digital financial innovations, which are emerging at a revolutionary pace in the financial system. In the digital age, it is necessary to create the conditions for competitiveness and security in the financial intermediary system. To understand this, we trace the process of how regulators move from a big bang-like market emergence through awakening and recognition to a confrontation triggering a need to act. This is followed by the period of task definition. Effective regulation requires both an analysis of the lessons learned from the period behind us and an outline of a possible vision for the financial intermediary system. A twofold task must be carried out: competitiveness requires the smooth progress of digital development, while the functioning of the financial intermediary system must not be impaired by more favourable operating conditions for digital financial innovations. The principle of "same activity, same regulation" needs to be enforced. Regulation must achieve a balance between these two interests, the absence of which results in regulatory arbitrage and asymmetry. Technological innovations serving payment services, artificial intelligence regulation and data protection need to be controlled. The process of searching for solutions and the desired regulation has been disrupted by the global COVID-19 pandemic, the economic and financial consequences of which have accelerated some stages of this process, while elsewhere they have had a slowing impact.

Journal of Economic Literature (JEL) codes: E58, G18, H21, O16, O36, O38

Keywords: FinTech/BigTech regulation, arbitrage, asymmetry, data-driven process, vision, taxation, social impacts

\footnotetext{
* The papers in this issue contain the views of the authors which are not necessarily the same as the official views of the Magyar Nemzeti Bank.

János Müller is an Economist and Chief Advisor of the Hungarian Banking Association.

E-mail: mulleri1@t-online.hu

Ádám Kerényi is a Researcher at the Centre for Economic and Regional Studies Institute of World Economics.

E-mail: kerenyi.adam@krtk.mta.hu
}

The Hungarian manuscript was received on 9 June 2020.

DOI: http://doi.org/10.33893/FER.20.1.103126 


\section{Introduction}

The disruptive effects of the Fourth Industrial Revolution have also affected the financial and banking systems in the past decade. In the second half of that period, so many profound changes took place that it would have taken as much as fifty years to adopt and process them during the previous revolutions.

It was necessary to realise that the progress of innovative digital financial developments was unstoppable and their existence and support constituted an essential condition for ensuring competitiveness and sustainable economic growth. At the same time, the advance of digital innovations in the financial market was so rapid, to the degree of even jeopardising stability after 2015, that their impact could be described as a "big bang". In this situation, one of the fundamental issue was to ensure the stability and the sustainable, competitive and profitable development of the financial intermediary system, i.e. the banking system. The process was multifaceted: in addition to FinTech-type service providers, large BigTech companies, FinTech unicorns and open banking appeared, along with the technologies required to operate these.

This process reached a point where warning signs emerged, with the manifestation of new types of risks that brought to the surface or foreshadowed systemic risks for incumbent banks which form the backbone of the financial intermediary system.

In our analysis, we stress the need to examine the situation as part of this process, in order to ensure security in the future. We show that, by the end of the previous decade, financial regulators and supervisors had worked out exactly how to support processes that strengthen competitiveness and how to amend regulations in order to ensure the security of the entire financial and banking system. International financial organisations have unanimously called for the harmonised international regulation of digital financial services. The principle of "same activity, same regulation" that is deemed necessary has not yet been implemented. Preserving competitiveness and financial stability requires regulation that provides a balance between these two interests, while regulatory arbitrage and asymmetry have emerged.

To effectively address this situation, it was necessary to analyse the financial market of the future and its various possible forms, and to assess the social and consumer impacts of digital financial innovations. Achieving these goals would preserve the competitiveness of the financial sector as a whole, ensuring the conditions necessary for incumbent banks catch up in digital terms and for the companies representing digital financial innovation to hold a share of the financial market which is not greater than optimal. Several different digital development scenarios (such as central bank digital currencies [CBDC], cryptocurrencies, crowdfunding) may influence possible regulatory symmetry, the realisation of a level playing field 
and the vision of the money market, but presenting these scenarios falls outside of the scope of this analysis.

\section{Stages of the FinTech phenomenon: market entry, the "big bang", recognition and confrontation}

The 2008 international financial crisis marked the beginning of a new chapter in the development of banking. It highlighted all of the shortcomings (including the not always harmonious cooperation between monetary and fiscal policies, in several cases) that paved the way for a crisis which caused severe damage and shook the whole system. A comprehensive arsenal of banking regulatory tools was elaborated at the international and national level to overcome the impacts of the crisis and restore the financial system. Within five to six years after the outbreak of the crisis, the banking system was restored to normal functioning, and in retrospect, we can conclude that the original mission of the banks and the traditional nature of their operations have not changed. The tasks of human-centred operation, maximum protection of banking secrets and client data, value preservation and value creation and financing sustainable economic growth have remained.

Digital innovations that fundamentally challenged the banking sector and were sometimes disruptive began to appear around the middle of the past decade. This phenomenon can be characterised as follows: FinTech solutions representing digital innovations burst into the market of incumbent banks, in a process that was so fast and so profound that it can be referred to as a "big bang" (Barberis 2020).

During this period, FinTech-type financial innovations were greeted with enthusiasm. Economic actors, central banks and regulators all welcomed the fact that incumbent banks had received competitors, which motivated them to develop their operations and forced them to reduce their costs. Incumbent banks' attitudes were also not critical, as FinTech enterprises - which mostly provided payment services - were not considered to be real challengers at the time.

Following the international financial crisis, the primary task of incumbent banks was to repair the damage caused by the crisis and to comply with the huge number of regulatory measures introduced due to the crisis. As a result, until the middle of the last decade, they lagged behind in the application and introduction of digital financial innovations and reacted late. This created an attractive space to be occupied in the financial market.

In addition to the positive reception, a number of favourable conditions facilitated the extremely rapid development of FinTech services. Conditions for founding start-ups were simple, with few obstacles: outfitted with just a little capital, it was possible to launch an activity that could quickly generate significant revenues with 
high turnover. It could be said that regulation was too lax: these enterprises were not considered to be financial institutions. Furthermore, enterprises of this type were helped and supported in a number of ways (regulatory sandboxes, innovation hubs). ${ }^{1}$ All of this was reinforced by the realisation that the support for and inclusion of digital development is an important condition for the economic competitiveness of the European Union and its member states.

We consider this stage of development as recognition. During the period of recognition, there was already a need to regulate digital innovation processes. To achieve this, the question of what to regulate had to be answered. Due to the rapid development and varied avenues of digital innovation, it was not possible to formulate a precise definition of FinTech activity. Consequently, even now the definition of FinTech-type digital activities remains loose and inclusive. Thus, we also apply this umbrella-type, broader definition in examining the search for digital innovation regulation in our analysis.

Within a short period of time, digital developments had an unprecedented impact on the human resources side of the banking sector. Incumbent banks needed staff members with new skills and knowledge, while they had to lay off many colleagues who had ensured previous banking operations. During the period under review, a number of analyses showed that global banks were also forced to significantly reduce their staff levels (excluding China) (see Table 1). Thus, FinTech competition forced them not only to develop technology and innovation, but also to provide new types of human resources.

\begin{tabular}{|c|c|c|c|c|c|c|c|}
\hline \multicolumn{8}{|c|}{$\begin{array}{l}\text { Table } 1 \\
\text { Number of bank employees per } 100,000 \text { inhabitants }\end{array}$} \\
\hline & 2004 & 2006 & 2008 & 2010 & 2012 & 2014 & 2016 \\
\hline Belgium & 666 & 631 & 603 & 555 & 534 & 496 & \\
\hline France & 638 & 657 & 693 & 661 & 657 & 634 & 634 \\
\hline Germany & 852 & 827 & 822 & 804 & 807 & 790 & \\
\hline Italy & 585 & 584 & 576 & 542 & 521 & 493 & 487 \\
\hline Spain & 557 & 573 & 586 & 552 & 495 & 438 & 407 \\
\hline United Kingdom & 644 & 632 & 644 & 609 & 567 & 559 & \\
\hline United States of America & 716 & 740 & 708 & 675 & 672 & 643 & 635 \\
\hline Japan & 209 & 202 & 219 & 223 & 219 & 217 & \\
\hline Australia & 683 & 720 & 722 & 674 & 627 & 651 & 654 \\
\hline China & 176 & 208 & 205 & 223 & 248 & 275 & 296 \\
\hline
\end{tabular}

${ }^{1}$ It should be noted that it was possible to use these forms of support in several countries, in principle by incumbent banks or financial service providers as well. 
In addition to employees, the number of banks fell sharply (Table 2).

\begin{tabular}{|c|c|c|c|c|c|c|c|}
\hline \multicolumn{8}{|l|}{$\begin{array}{l}\text { Table } 2 \\
\text { Number of banks }\end{array}$} \\
\hline & 2004 & 2006 & 2008 & 2010 & 2012 & 2014 & 2016 \\
\hline Belgium & 104 & 105 & 107 & 107 & 104 & 103 & 90 \\
\hline France & 820 & 763 & 658 & 638 & 611 & 563 & 529 \\
\hline Germany & 2,400 & 2,301 & 2,169 & 2,093 & 2,053 & 1,990 & 1,888 \\
\hline Italy & 778 & 793 & 799 & 760 & 706 & 664 & 604 \\
\hline Spain & 266 & 271 & 280 & 274 & 249 & 219 & 206 \\
\hline United States of America & 8,976 & 8,680 & 8,305 & 7,658 & 7,083 & 6,509 & 5,913 \\
\hline Japan & 407 & 396 & 387 & 379 & 377 & 373 & 370 \\
\hline Australia & 50 & 53 & 55 & 54 & 66 & 70 & 82 \\
\hline China & 88,150 & 19,797 & 5,634 & 3,769 & 3,747 & 4,089 & 4,398 \\
\hline
\end{tabular}

In the second half of the 2010s, the actors, regulators and supervisors in the financial intermediary system reached a common agreement that this process was unstoppable. The time had come for recognition and confronting the challenges of the situation.

Rectifying the lack of regulation and the need to do so is justified by the fact that the emergence of FinTech-type services has both accelerated access to financial services and been able to disrupt traditional financial processes. These developments generate significant privacy, regulatory and law-enforcement challenges (Philippon 2020:2). In addition to the many advantages of digital development, it has become clear what issues need to be resolved by regulators in order to ensure the stability of the financial system. In this process of recognition and confrontation, international financial organisations have also come to understand that the benefits arising from payment services pose risks in terms of operational, data protection capability and the protection of clients' investments. All of this can lead to the effect of digital exclusion (BIS 2020:1).

Asymmetry between the operating conditions of the two groups - incumbent banks and digital financial service providers - was already observed at an early stage in their operations. While incumbent banks operated under a strict regulatory regime, FinTech start-ups entering the market essentially "mobilised" client deposits with banks and client funds using innovative digital technologies, primarily by providing payment services. The costs and service fees of these start-ups were extremely low, while incumbent banks bore the costs of safely managing deposits and current account money placed with them, and paid interest on deposits. These resources are available to FinTech enterprises with no cost or fee. 
It should be noted that these enterprises are active service providers primarily in the areas of payments and thus their regulatory classification and type of activity is different from that of a credit institution. Recognising this regulatory dilemma, the European Union reaffirmed the existing principle, adopted by most member states, that the same activities should be subject to the same regulation. Application of this principle is not self-evident even for the individual member states, because in many cases the emphasis is on the service, while in other cases it is formulated as a requirement in relation to the activity. It has also been known from the outset that digital financial service providers carry out cross-border activity as well, essentially without regulation, although undoubtedly some of them requested authorisation to do so when registering their activity. The European Central Bank (ECB) has indicated that international cooperation and regulation are necessary to manage the processes, but implementing this has not been feasible to date. It was thus decided that most of the regulation of innovative digital services should remain a national competence. At the same time, it must be understood that Europe has a layered regulatory environment that manages regulatory frameworks in a uniform way; within this, in some cases, there is room for manoeuvre in the member states or a supervisory role at national level, and in several cases, regulations (directives) are applicable at the European level.

The aforementioned asymmetry was exacerbated by the fact that, having overcome the difficulties of the crisis, incumbent banks - lacking an adequate toolkit responded more slowly to rapid digital processes, and were thus slower to adapt and also slower to create the operating conditions for such processes. Another such factor was the emergence of BigTech service provider companies, which, in addition to payment services, had already been engaged in lending and other banking activities.

\section{Future landscape of transformation in the financial intermediary system}

In light of the lessons above, it was necessary to decide what operating conditions and regulatory frameworks should be established. In order to ensure stable regulation, the expected vision and social impacts of the financial market had to be assessed, in addition to the already known impacts of digital financial processes. In evaluating the vision, analysts did not focus on the unforeseeable future, but rather on the changes expected in the medium term, examining the set of conditions for the future functioning of the financial market and conceivable alternatives and opportunities for a financial system being transformed by digital development.

At the start of the 2020s, analysts outlined the following identifiable framework conditions for the operation of the financial system: 
- The spread and transformative impact of digital processes in the financial sector is unstoppable.

- The primary goal is to make maximum use of the positive impacts they provide.

- The risks of FinTech and other digital services must be identified at the same time, and efforts must be made to filter out these risks and mitigate the negative impacts.

- Identical regulation for the same activity of incumbent banks and FinTech service providers and BigTech service providers entering the market must be ensured, thus creating a level playing field; otherwise the sustainable financing and stability of the economy will be damaged.

- Strong emphasis should be placed on the regulation and monitoring of technological innovations (Distributed Ledger Technology [DLT], Application Programming Interface [API], Biometric and Cloud-Based Technology), artificial intelligence (Al) that enable FinTech-type services, and, along with these, on data protection.

Given the history of economic cycles, it was necessary to prepare for a possible slowdown in economic growth, even for the onset of an international recession. Trade wars, geopolitical tensions and efforts to change international power relations and the prospects of the post-Brexit European Union called for a stable, shockresistant European economy, with secure and sustainable financing of the economy as a primary requirement. An increasingly important new requirement for this among many other things - is success in international digital competition. ${ }^{2}$

Along with sustainable financing, in their outline of the future landscape of European financial services, experts highlighted the radical transformation of client preferences and needs, the improvement of so-called client experience and the corresponding transformation of services. As digital financial changes considered revolutionary were already described as disruptive in the initial period, one of the first requirements formulated was that the banking system and incumbent banks must "disrupt" themselves, i.e. banks must develop new business models by necessarily taking into account the impact of financial services and service providers based on technological innovations. These developments were summarised clearly by the BIS Financial Stability Institute, according to which "FinTech can lead to significant positive development but it transforms financial services and also comes with potential risks to consumers and investors and, more broadly, it may pose a risk

\footnotetext{
${ }^{2}$ It should be noted that at the beginning of writing our analysis, the coronavirus pandemic was not yet present in Europe; at that time, we did not yet consider its possible economic and financial impacts.
} 
to financial stability and integrity. Therefore, it is the task of regulators to help bring about positive impacts, while seeking to mitigate these risks" (FSI 2020:2).

A precursor of the examined vision was the EU "Payment Services Directive II" (PSD2) introduced in 2019, which obliges incumbent banks to ensure - with the consent of their clients - that their accounts with the bank can be accessed by external third party providers (TPP).

The stated aim of this directive was to strengthen competition in the banking market by involving digital financial service providers. This so-called open banking is indeed disruptive and, at the same time, is one of the building blocks of a subsequent possible digital financial marketplace. Incumbent banks will or may also be actors in this marketplace, but the vision outlined does not provide information as to how and based on what criteria its operation should be regulated. This directive made banks realise that their turnover and revenues were threatened by serious competition, and that they had to accelerate their digital developments. Banks were concerned that the process had started under unequal regulatory conditions, and analysts had identified several potential risk factors. Although third party providers can obtain client account information after a rigorous identification procedure, it is difficult or impossible to verify whether a given TPP has concluded a subcontracting service contract (e.g. digital, innovation applications, new interfaces) with another company, which could allow client data to escape from this circle.

A PWC analysis considers the so-called "amazonisation" to be one of the possible, inevitable financial market developments of the period ahead (PWC 2019). The essence of this is the creation of a digital financial marketplace, a client-centric interface where retail and company clients are able to find the products and services they need at the best price and under the most favourable conditions. At the same time, they will perceive the overall assessment of this virtual financial market for them, and the views and comments of searchers. These platforms allow for transparency and comparability. Sophisticated technological solutions open up a new opportunity to distribute and share services. "One-stop shopping" becomes possible, where services can be compared and the selected "financial product" can be obtained in one place. According to PWC's vision, millennials will soon be the dominant actors in the market, forcing a twofold impact: firstly, there is a real need to create an amazonised financial marketplace; secondly, they are consciously monitoring "key performance indicators (KPI)" and can make bilateral financial decisions based on them (PWC 2019). 


\section{Social and consumer impacts of the digitalised financial sector}

In examining the vision of the future, we must discuss the social and societal impacts of digital developments affecting the financial sector. In modern economic history, scientists have always been interested in the forces that technological and social innovations and their interaction unleash and how they affect economic growth. Historical experience shows that people have generally been positive about the achievements of modern technology, trusting that they will help them realise their dreams. Let us assume that the digital processes examined are in line with the will of people. The question is, however, whether these developments in the financial sector will, without exception, make our dreams come true. With the help of a few examples, let us review the relationship between the new reality that is dreamt of and the reality after awakening. The first point where changes are profound is the transformation of the traditionally human-centric nature of the banking system. As outlined above, banks' traditional business model was based on human relationships: it was a human-centred, trust-based profession. One important requirement was the physical availability of the bank and in many cases personal contact with the staff. Even before the emergence of FinTech, there were tools to replace personal contacts, but the protection of bank secrecy and the human-centred nature of the business remained the same. Today, by contrast, an increasing proportion of financial transactions cannot be carried out without an internet connection, a computer or a smart phone. In other words, we as clients depend on these devices and the data they use, we are not tied to the bank and we have a different approach to the protection of our valuables and data kept by the bank.

In the period ahead, the banking sector needs to be prepared for the fact that a substantial proportion of its clientele will be millennials (PWC 2019). Their financial culture requires digital financial services and they will be the active users of the digital financial marketplace offered by amazonisation. They have no, or minimal, risk sensitivity toward FinTech-type financial services, nor are they bothered by the fact that Al-based programmes profile them, based on the data collected about or from them. In addition, by using this, the appropriate technology programmes will find them in the marketplace with customised offers.

A number of examples and analyses show that banking/financial/payment services are expected and required to have digital applications and to provide - what we call - a new type of "client experience". Speed, instantaneousness and electronic remote administration have come to the fore - and today not just in the case of payment services. At more and more incumbent banks, opening an account no longer requires the presence of the client, the identification of the person or, for example, credit assessment is done using electronic applications. These processes 
have two consequences. Firstly, consumers' openness to Al-based services and the need for instantaneousness reduce or obscure risk sensitivity. Secondly, the need and opportunity for personal banking is reduced. The negative consequences of this the former are reflected in the significant amount of damage caused by the activities of larger FinTech-type companies, and in the case of the entry of BigTechtype companies, it is clearly demonstrated that their clients are not aware of the nature of the data use by these companies and its possible negative impacts.

Although these processes have been accelerated by the impacts of the COVID-19 pandemic, this does not mean that personal client relationships or bank branches will not be needed, albeit the latter may only be needed in significantly smaller numbers.

The increasing application and use of services based on digital financial innovations has triggered the need to strengthen digital financial awareness at the national and international levels, primarily for the benefit of consumers but also for service providers, in an effort to reduce the risks in this area. With this in mind, the European Banking Federation has organised its financial awareness cooperation programme, ${ }^{3}$ and the Pénz7 (Money Week) of the Hungarian Banking Association and the Financial Compass Foundation have similar objectives.

The next stage of transformation is the growing social impact of BigTech companies, which - based on their trade turnover and the huge amount of data they collect are entering the lending market more and more aggressively and are able to provide cheap, low-cost credit as their clients pay part of the cost of credit with their data; furthermore, they realise a remarkable part of their profits through the resulting increased trade turnover.

In social financial literacy, the result of this is that when people need credit for higher value purchases, they no longer think of banks, or just banks. Thus, a kind of desirable client experience is realised, either in terms of cash flow or lending, but its price and risk do not yet trigger a bitter awakening.

The order of credit assessment and credit rating is changing. Credit assessment is increasingly performed by computer programmes based on the information and data entered. The quickly obtained result can no longer be questioned by clients: they accept the machine's decision, saying that the machine cannot be biased or inaccurate. The possibility for empathy is excluded from banking operations, although in human-centred incumbent banks it could be part of client relationships - provided that all the rules were adhered to. Similar processes are expected to emerge in asset and wealth management, where investment advice and the "movement" of assets are also performed by Al-based algorithms and robo-advisers.

\footnotetext{
${ }^{3}$ https://all-digital.org/events/european-money-week/
} 
It is indisputable that digital financial services have many advantages and positive impacts. We should be happy and welcome it if the emerging new world is hopefully better than the old world. At the same time, the following question cannot be avoided: Do digital financial changes always result in better things, or do they also reflect the manipulative impact of revolutionary novelties, along with their risks? Digital financial innovations were initially described as a new normal. Not long thereafter, the question arose as to whether the reality of these changes could be known, how to obtain reliable knowledge, and what the truth was.

We are confronted with a valid question: When most users know and experience only the service side of the digital financial process, does this world of experience lead to reliable knowledge, i.e. the truth about the benefits/risks of the FinTech/ BigTech process? Are we able to see into the processes, the maze of data usage, the hidden but existing, potential risks of the system? The incompleteness of reliable knowledge may be indicated by the fact that shortly after its explosive appearance on the market, FinTech was described as "a new normal"; or when one of the tasks of the period ahead was formulated, it was said that digital services should provide a "new client experience". Here is another question: Is it possible that the need and search for a new experience keeps us from learning about the possible risks?

All of these developments will transform the organisational and operational order of incumbent banks, significantly fewer and differently qualified human resources will be needed, and the physical availability of banks is no longer a fundamental requirement.

\section{The "Catch-22" of regulating digital financial processes ${ }^{4}$}

\subsection{Searching for the possibility of a balanced regulation}

As a result of the process of confrontation and recognition, regulatory tasks reducing risks and strengthening financial stability and the need for such were clearly identifiable. The primary regulatory task is to strengthen the stability and security of the financial intermediary system, including the prevention of systemic risks, the creation of a level playing field and ensuring the security of data use. One sensitive area of regulatory tasks is to strike a balance between maintaining and even strengthening international competitiveness and minimising the potential risks of digital financial services. Due to their nature and system of tools, these financial services are mostly cross-border in nature.

\footnotetext{
${ }^{4}$ In the title of this chapter, we refer to the novel "Catch-22" by Joseph Heller and the legendary American film based on it. The expression in the title refers to a situation in which we cannot make the right decision, regardless of which possible solution we choose. Decision-makers must continually strive to strike a balance between multiple, simultaneous challenges.
} 
Regulatory issues need to be examined in parallel with the development process of financial innovations, because although operating licenses or the imposition of certain conditions were in place from the outset, the rapid developments increasingly highlighted the fact that certain forms of conduct or supervisory guidelines, and the fragmented, unequal national regulations were no longer sufficient. At the current stage of development, which we call the period of confrontation in our analysis, the task is specifically to implement the regulatory tasks identified, not only at the national level, but, for example, in the EU at the international level as well.

The fundamental question is whether the desired international regulation, and within it at least a common minimum rule, is achievable, or, as proposed by the $E C B$, the majority of regulatory tasks should remain a national competence. It has become a generally accepted principle that the same activities should be subject to the same rules, i.e. the operation of incumbent banks and innovative digital financial enterprises should be given a level playing field in the money market. The question rightly arises: If one of the actors receives support from several sides (e.g. permitting the financial activity, tax allowances), however, its operation is not subject to the necessary majority of banking rules, if bank client data become available (albeit conditionally) to FinTech service providers, then how should the implementation of a level playing field begin: by easing banking regulations or by tightening that of the FinTech?

To answer the valid questions, the President of the Hungarian Banking Association gives a clear answer: "We also like fair competition. Today, foreign financial service providers called FinTechs can operate cheaper than Hungarian banks in certain areas, among other things, because they do not pay the mandatory taxes, i.e. the transaction tax, do not apply data protection and other regulations required of the banking sector, do not maintain a branch network, do not deal with costly, less profitable areas and are not monitored by the MNB."

The Hungarian Digital Success Programme also envisages the creation of a regulatory balance, aiming, among other things, to establish regulatory frameworks that stimulate both FinTech innovations and the digital developments of incumbent actors in the financial sector, and that are favourable for the competitiveness of the national economic and financial system as well.

Another area of the regulatory trap is the separate or activity-specific joint regulation of digital payment and financial services and the digital technologies (AI, DLT, API) that serves them. Without this, regulation of the operation of the examined activity cannot be considered complete. Without disputing their usefulness and indeed

\footnotetext{
${ }^{5}$ Radován Jelasity: Szeretjük a tiszta versenyt (We like fair competition). Piac és Profit, 2020/1. https:// piacesprofit.hu/kkv_cegblog/jelasity-radovan-szeretjuk-a-tiszta-versenyt/. Downloaded: 7 June 2020.
} 
confirming it, we can raise the question: When will it be possible to extend the conditions of the desired national and international regulation to this area as well? The control, regulation and supervision of BigTech activity presents a particular challenge, which we will discuss later.

As shown above, by the beginning of the 2020s, sufficient information and experience had been gathered to formulate a realistic vision, on the basis of which regulatory tasks should be defined. In January 2020, the BIS Financial Stability Institute published an analysis reviewing the cross-border requirements of FinTech regulation and summarising the regulatory tasks of FinTech activities and the technologies that served them (FSI 2020).

Recognising these requirements, in February 2020, the European Commission (EC) published a data strategy for the digital future of the European Union (EC 2020a), based on the then-published "White Paper". Strategic materials outlining Europe's digital vision can provide a background and framework for the development of a regulatory system for digital financial processes in the region. The stated aim of the strategy is to make Europe a globally competitive, value-based and inclusive digital economy and society, ensuring that it maintains its open but rules-based market and continues to work closely with its international partners (EC 2020b).

In the context of our analysis, one important objective of the strategy is to "create a genuine European data space, i.e. a single market for data, which would make untapped data available so that it can flow freely within the European Union and between sectors" (EC 2020a). This data space can actively contribute to realisation of the amazonisation outlined above.

The above objectives are indisputably important, but they create a sense of absence, as a key element in economy, the financial sector is not mentioned among the sectors listed in the strategy material, furthermore, it is not clear whether Alsystems used in the financial system are considered high-risk, as their regulation is subject to a different jurisdiction. Hopefully, this is the case, where guaranteed human supervision would also be a top priority. It is a positive decision that the objectives of the White Paper should be achieved by the end of the five-year cycle starting in 2020, but this time-frame may prove to be too long, given the speed of digital processes.

The Common European Data Space plans to lay down new rules on cross-border data use and data interoperability. The conditions for data access and data use will be regulated. In the Commission's view, regulatory instruments should ensure the competitiveness of the European Union in the digital sector on the basis of three pillars of activity, namely, by means of technology for people, a fair and competitive digital economy and a digital and sustainable society. In this Bermuda 
Triangle of regulation, the aforementioned White Paper is of key importance, as it will represent the introduction of the Digital Services Act (DSA), providing a legal framework for data management. Analysing the search for a way out regarding digital regulation, we consider the European Parliament's (EP) recommendations of April 2020 to be an important step forward, in which the EP makes legislative proposals to the EU Commission on digital services to improve the functioning of the single market (EP 2020). This also means that the legal regulation of some of the issues affecting our analysis has already started and is in progress. In this regard, we would highlight the proposal for ex-ante regulation of systemic platforms, according to which DSA should "set up an ex ante mechanism to prevent (instead of merely remedy) market failures caused by 'systemic operators' in the digital world, building on the Platform to Business Regulation" (EP 2020:17). Another important element in strengthening balanced European competition rules is the issue of digital taxation, which we will write about later.

In order to move forward, the European Commission set up an expert group ("Expert Group on Regulatory Obstacles to Financial Innovation - ROFIEG"), which, at the end of 2019, summarised the regulatory obstacles and assessed what to do in the period ahead. In their report, they note that many of the risks arising from the use of FinTech are not different from those associated with traditional financial services, so it is not possible to draw a clear line between the potential risks of "traditional" and "innovative" financial services. Innovative technologies can both increase and reduce these risks (ROFIEG 2019). The risks identified by the expert group can help make the necessary regulatory decisions, and they urge that such decisions be made. For example, it is found that the financial market, like other areas, creates opportunities for activities that are contrary to market integrity (e.g. market manipulation) or for abuses in the form of criminal offences (money laundering, tax evasion, purchase of illegal goods or services, etc.). However, the use of FinTech can also pose entirely new risks, for example: a) If decisions are carried out by Al-based "black box" algorithms without human intervention or which are not understood by clients or supervisors. b) Distributed ledger records or case management blur regulatory and legal responsibilities, which are traditionally based on bilateral agent-agent relationships. However, the expert group has not yet made proposals for specific regulatory decisions.

At the end of the last decade, both the International Monetary Fund and the World Bank dealt extensively with the impacts and benefits of digital financial innovations and the need for their regulation (IMF 2018). These two organisations also emphasise the need to find the right balance between financial innovation, the strengthening of competition, commitment to open, free and competitive markets, and addressing the challenges of financial integration, consumer protection and financial stability. 
Analysts from these two global financial organisations have called for close international cooperation and coordination to eliminate regulatory deficiencies and avoid risks associated with the decline in regulatory compliance. The report issued by the International Monetary Fund states: "Many fintech risks might be addressed by existing regulatory frameworks. However, new issues may arise from new firms, products, and activities that lie outside the current regulatory perimeter. This may require the modification and adaptation of regulatory frameworks to contain risks of arbitrage, while recognizing that regulation should remain proportionate to the risks" (IMF 2018).

In addition to the positive aspects of the analyses of the two international organisations, it should be noted that their proposals do not include the appropriation and possible content of specific action, while the risks of disrupting the financial stability and the financial intermediary system are present, i.e. here, too, the dilemma of regulatory arbitrage arises.

In the foregoing, we reviewed in detail the further development options elaborated or proposed by international organisations for proper regulation of the financial sector. As seen, the need to achieve a level playing field is now widely accepted, but substantive decisions were not made on the grounds that efficiency and competition were necessary. This justification also has a self-exculpatory nature, as the issue should be considered in its entirety, including financial services, data management, financial data security, the application of artificial intelligence or robotics. While maintaining the known and desired digital benefits, we should not ignore the risks of fragmenting and dismembering the financial services provided by incumbent banks.

Supporting this line of thought, let us consider the so-called GDPR (General Data Protection Regulation) rule as an example, which is mandatory in the EU for the protection of personal data: pursuant to GDPR, all financial institutions must ensure the protection of client data, giving their clients the absolute right to inspect their data and be in control of them. Then, the EU's payment services regulation PSD2 (Payment Services Directive II) was issued, which (to strengthen competition, as it stated) allows licensed non-banking service providers to access bank client data in order to render their financial and information services. This change in itself had several consequences: it disrupted the financial market, fragmented the former unity of deposit and payment transactions and lending, abolishing one of the main tasks of banks: the exclusive protection of bank secrecy on the basis of client data protection. Namely, in our view, the "utilisation" of client data already held by third party providers cannot be fully controlled; due to the outflow of part of the data volume held by banks, incumbent banks have been put at a remarkable competitive disadvantage vis-à-vis financial innovation digital companies. The term "regulatory arbitrage" fits well with this situation, when the need to strengthen competition and 
to control market processes appear again at the same time. The European Banking Authority (EBA 2020) has also affirmed the importance of balanced regulation and identified four key pillars: data management; technology infrastructure; organisation and governance; and analytics methodology.

As a new element in digital financial services, central bank digital currency (CBDC) has emerged. Although an analysis of this issue is beyond the scope of this study, we will briefly address it, as its impact on the financial intermediary system will be noteworthy in the near future. The introduction of CBDC may have advantages: it could make the payment system more efficient and cheaper, strengthen economic integration and cross-border payments, and monetary policy could take on a new dimension. At the same time, assessing and managing potential risks in terms of regulation, and thus stability, is a priority. From the point of view of the banking system, the first possible risk is a departure from financial intermediaries, a disintermediation of the normal chain of the financial intermediary system, when clients transfer their deposits with the bank to CBDC holdings. In this situation, banks are forced to pay higher interest rates in order to retain deposits and to raise funds that reduce their profits, which ultimately makes lending more expensive or forces a reduction in collateral.

\subsection{The emergence of BigTech - another trap of regulation}

Thus, at the beginning of the decade that began in 2020, it can be seen that the disruptive impact of FinTech enterprises in the incumbent banking market has been relatively marginalised, partly due to the digital catching-up of banks. However, BigTech companies appearing in the meantime are breaking into and opening up a breach in the money market.

The next big challenge of regulation, as mentioned above, is the supervision and control of BigTech companies entering the market after the emergence of FinTech financial services. Some of these are capable of disrupting financial markets, sometimes entailing systemic risks. Numerous analyses point to the financial market risks of BigTech-type companies such as Facebook, Google and Amazon. After the big bang of FinTech in the money market, the penetration of BigTech companies into the financial market meant a paradigm shift in terms of regulatory tasks. While FinTech enterprises disrupted the formerly uniform structure of the banking market primarily in the area of payment services using their innovation tools and mainly relying on the data and client bases of incumbent banks, BigTech broke into the market by utilising the already data-driven system of the economy, triggering an ever-deepening transformation process.

BigTech companies have a huge body of data and a large number of users, which allows them to build a "platform strategy", taking over an increasing proportion 
of the tasks of the financial intermediary system. "In this decade, however, a new type of disruption of the financial system has emerged, which is a platform strategy. BigTech has gained unparalleled experience in this area and has therefore a competitive advantage over incumbent banks. BigTech business models are built on network effects and there is no reason why they should not apply this logic when launching financial services. In other words, while FinTech has brought competition, BigTech will result in concentration" (Dahdal et al. 2020:1).

BigTech companies operating on a network basis with large amounts of data present regulatory authorities with a real challenge. Due to their size, these giant companies represent systemic risks; they are too large for their financial activities to be controlled and regulated by a single jurisdiction. In relation to the data volumes and client access available to them, basically, they do not obtain them through financial activity and client relationship, however, with the approval of their clients or indirectly, and they also have access to bank client data. Due to their amazonised, data network-based activity, information asymmetry is developing between them and incumbent banks, and regulators have so far been unable to find a solution to this competitive disadvantage. In this regard, incumbent banks may have the option of entering the digital financial marketplace, although they may thus open up another data outflow channel. Another realistic scenario is that BigTech platforms will be wedged in between banks and their clients. "Big Tech firms may become banks and leverage their superior information about consumer preferences, habits, and conduct; they can control the shopping experiences of many consumers. [...] They have not only superior big data but also an advantage in terms of the tools (e.g., Al algorithms) used to analyse them in order to understand customers' needs and influence them" (OECD 2020:22). While BigTechs have extensive, up-to-date information on their clients' purchase patterns and preferences, clients only receive information on the services they use and are mostly unaware that they are paying for some of the services with their data. Information asymmetry can also be found between incumbent banks and their clients, usually in favour of the banks, but this is limited by a number of laws, obliging banks to provide as much information as possible. For BigTech companies and their services, there is a crossborder stratification of data protection systems, resulting in fragmentation of the international market. Companies registered in certain countries with limited data protection systems may refuse the operation of other jurisdictions, because they are not subject to the given country's regulation.

One of the key issues in the indispensable regulation of digital financial processes is taxation. In fact, the European Commission has set a target for the taxation of digital giants, where much of the companies' revenue comes from the value generated in the data economy. However, generally, these revenues are not taxed where they are created, which distorts competition and reduces the tax base of the societies. 
The European Commission has also proposed a reform of corporate tax rules, whereby profits should be declared and taxed where the given enterprise maintains a significant relationship with users through digital channels. Similarly, discussions are taking place at the international level for a consensus-based, long-term and global solution. According to the schedule adopted by the G20, such a solution should be developed by the end of 2020. Negotiations on the international taxation of the digital economy are led by the Organisation for Economic Co-operation and Development (OECD). At the same time, several member states of the European Union (France, Italy, Spain and Hungary) are planning to introduce targeted taxation on digital giants and would, in principle, support its international extension.

Based on the above, it can be seen that the directions and conditions for the development of balanced regulation have been realised. However, due to the COVID-19 pandemic, in the field of financial regulation, regulatory processes classified as urgent prior to the pandemic, are fading into the background and temporarily slowing down.

\subsection{A brief overview of the Hungarian FinTech regulation}

Hungarian digital financial processes have followed the developments of the international mainstream in recent years. The start-up conditions were favourable for FinTech start-ups, and they received a number of supports for their growth. The central bank made it possible for digital financial innovations to take advantage of the opportunities offered by the Innovation Hub and the Regulatory Sandbox.

Progress was rapid and fruitful in many respects; by the end of the previous decade, digital innovations became major actors in the financial ecosystem. By 2020, more than a hundred FinTech-type companies were operating successfully in the country. Some of them provide B2C, but most of them provide B2B-type services. It became clear that there was a need for cooperation between ecosystem actors, incumbent banks and companies representing digital innovations.

Realising this, experts developed Hungary's FinTech strategy in May 2019 (Digitális Jólét Nonprofit Kft 2019). The strategy within the framework of the Digital Success Programme aims to promote the development of the sector even with budgetary resources and to remove regulations restricting development, whereby innovative technological solutions will result in simpler, cheaper and more convenient administration for clients and increased competitiveness for the economy. A process started, in which the FinTech strategy of the Magyar Nemzeti Bank (the Central Bank of Hungary, MNB) was published in October 2019 (MNB 2019). The strategy concerns initiatives within the MNB's remit that encourage the introduction of new services to the market. One of the key elements of this is the need to create a regulatory environment that takes into account changes, supporting positive innovations, while taking effective and rigorous action against excessively risky, 
unethical or harmful behaviour in an effort to strike the right balance between these two objectives.

In cooperation with government bodies, in the autumn of 2019 the Hungarian Banking Association elaborated a comprehensive concept supporting digital development, on the basis of which negotiations on the proper functioning of financial innovation services were launched in cooperation with the relevant government bodies. "The regulatory and supervisory environment will even be decisive for banking digitalisation: if the rules imposed on FinTechs/BigTechs are looser than the ones imposed on banks, digitalisation will take place in a non-level playing field and with more risks for clients than what should be allowed" (Becsei et al. 2019:303).

To achieve the desired, successful digitalisation, the entire financial sector has to confront new challenges. The heads of the Magyar Nemzeti Bank and the Hungarian banks agreed that the big winners of the economic impacts of the COVID-19 pandemic are clearly BigTech companies, which are now able to cover the entire financial value chain and not only have considerable capital but also control massive data assets and are able to enter the financial services market. ${ }^{6}$ BigTech companies have an advantage over commercial banks in regulatory arbitrage. The banking sector is an extremely strictly, highly regulated, controlled sector, which entails enormous costs to it. Banks must now compete with these companies in a setting in which they are subject to different rules. It is a common position that a level playing field is needed.

Furthermore, the member banks of the Hungarian Banking Association have drawn up a list of the focal points of digital transition in banking and formulated their proposals in support of digital transition. These include reducing high cash use by digital payment solutions, expanding and optimising digital lending and client service processes, reducing the administrative expenses of bank operations and continuing to strengthen education that incorporates digital finances (Becsei et al. 2019).

The Magyar Nemzeti Bank is participating in several international initiatives aimed at regulating the standards of conduct of FinTech processes. A precursor of international regulatory initiatives was the Global Financial Innovation Network (GFIN), which created a cross-border regulatory sandbox, as well as the Londonbased Financial Conduct Authority (FCA), which aims to establish a link between regulation and fair FinTech regulation (Müller - Kerényi 2019). The MNB has joined the GFIN and has a close professional relationship with the FCA.

\footnotetext{
${ }^{6}$ Nagy, L.N. (2020): Egyenlő elbánást kérnek a bankok (Banks call for equal treatment). Világgazdaság. https://www.vg.hu/vilaggazdasag/vilaggazdasag-penzugy/egyenlo-elbanast-kernek-a-bankok-3100030/. Downloaded: 3 October 2020.
} 
In April 2020, the MNB's FinTech and Digitalisation Report was published (MNB 2020a). The document provides an overview of domestic digital processes and classifies the level of digitalisation in the domestic banking sector. It considers the latter to be a good medium level, applying perhaps a too strict standard, because in the last few years the digital capabilities and innovation services of Hungarian banks have taken a remarkable step forward.

The Magyar Nemzeti Bank is closely monitoring the market trading of cryptocurrencies: one indicative step in this regard was the warning issued in connection with the activities of certain FinTech companies operating in the country (MNB 2020b). These warnings also contain important indications for the future: They lay down that (1) the MNB only supports the operation of these types of companies if they guarantee financial stability and client security, and (2) it takes decisive action against cases negatively affecting consumers in Hungary, even if - in case of cross-border activities - its supervisory tools are limited.

The above reaffirms that with regard to cases identified in connection with foreignowned companies, only the supervisory authorities of the home country can act, even if such cases endanger stability or consumer security; the MNB's consumer protection powers are limited.

In April 2020, the Hungarian Fintech Association was established. Its statutes contain the generally accepted objectives of financial associations (Hungarian Fintech Association 2020). Start-ups, mature enterprises, incubators and accelerators joining the Hungarian Fintech Association "agree with the goals of the association, and through their own technology-focused activities, support the functioning of financial service providers and banks in the market (servers), or by means of their innovative solutions have a disruptive business model to meet the financial needs of retail/ company clients (challengers)" ${ }^{\prime \prime}$.

It is thought-provoking that the Hungarian Fintech Association considers incumbent banks to be servers, obviously not referring to the fact that banks are serving their own clients. In the light of this vision, banks should be the "servers" of FinTech companies, presumably to achieve a better client experience. If this is the case, it should appear in the requirement of same regulation.

Due to the COVID-19 pandemic, FinTech processes have continued to accelerate since the beginning of this year in Hungary as well. Among other things, the central bank has already registered five Hungarian companies, together with a company called Koin, which can operate as account information service providers (AISP). ${ }^{8}$

\footnotetext{
${ }^{7}$ Rácz, G. (2020): Megkezdi tevékenységét a Magyar Fintech Szövetség (The Hungarian Fintech Association has begun its work). Napi.hu. Downloaded: 7 June 2020.

${ }^{8}$ The AISP has access to the user's payment account balance and transaction data with the user's authorisation. It may use the data to provide additional financial services.
} 
AISP companies not only gain insight into bank clients' account balances, but can also track all of their payments and purchase patterns, which is a way of entering into cooperation agreements with other FinTech service providers, as has been the case with Revolut. Of course, they do not pay a fee to the bank for the use of client data managed by banks and secured, inter alia, by deposit insurance guarantee and for money transfer from there. Thus, open banking continues to expand in Hungary too, along with its advantages and risks due to regulatory gaps.

Based on the above, we can conclude that the development of FinTech and digital innovation in Hungary is moving in the right direction. The MNB, together with the Hungarian Banking Association, is actively following international processes, and has joined some of them, and consultations have begun between the Hungarian banking community and financial government bodies to strengthen digital competitiveness. However, the COVID-19 pandemic temporarily modified the focal points of this process.

\section{Summary}

The regulatory requirements, goals and aspirations of diversified, digital financial innovations with more and more new elements are constantly spinning like a perpetuum mobile. This perpetual-motion "machine" is consuming a lot of energy, however, the question is: How and when will it reach its destination? When talking about regulation and searching for a way out, we are looking for a chain of international, national legislation, central bank or supervisory measures that ensure the same regulation of the same activities in each area of the financial intermediary system, from capital requirements to taxation.

In this process, we have followed the course of digital innovative financial developments, from the big bang through recognition to the confrontation and then, by outlining the future landscape, to defining tasks. The experience of confrontation has made it possible to evaluate the digital innovative processes that back up the financial system of the future, and to identify their need for support. At the same time, it has also become clear that incumbent banks, constituting a key factor of the financial intermediary system, must be protected from the damage that might be caused by new digital actors in the market. The task is therefore twofold and complex: the sustainable financing of competitiveness and economy requires the creation of a set of operating conditions that is supportive and permissive where it is necessary and, at the same time, provides strict control, monitoring and restrictions where risks and systemic problems occur. In solving this twofold task, we must find a delicate balance that reduces the potential for regulatory arbitrage and regulatory asymmetry, i.e. we must ensure a level playing field. Having inspected the sometimes complex labyrinth, we can conclude that neither the 
European Union nor the Hungarian practice is on the wrong track, although the condition of "same activity, same regulation" has not yet been met. Nevertheless, in the first year of this decade, work towards a solution has been launched, however, the COVID-19 pandemic has had a twofold impact on this simultaneously: in some areas, it has accelerated the development, while in others, it has resulted in a hopefully temporary - slowdown.

This is the only way to realise a level playing field, which has not yet been achieved. Developments have already taken place in various areas, even through international cooperation, but these have mainly regulated the ethical requirements and standards of conduct of FinTech.

These initiatives have been important in themselves, but one of their key added values is to explore the functioning and potential risks of areas in need of regulation, and thus to provide guidance for the development of a comprehensive regulation. Proceeding along this path, a number of regulatory initiatives have been launched and are under way, several of which we have presented, along with the difficulties and simultaneous urgency of the task, as it is nothing less than the stability of the financial system and the prevention of risks to it that is at stake.

\section{References}

Barberis, J. (2020): BigTech vs BigBang: Competition in Financial Services. https:// oecdonthelevel.com/2020/01/20/bigtech-vs-bigbang-competition-in-financial-services/. Downloaded: 5 June 2020.

Becsei, A. - Bógyi, A. - Csányi, P. - Kovács, L. (2019): A jövő bankja, a bankok jövője - A Magyar Bankszövetség digitalizációs javaslatai (The bank of the future, the future of banks - Digitalisation proposals by the Hungarian Banking Association). Gazdaság és Pénzügy (Economy and Finance), 6(3): 299-310.

BIS (2018): Structural changes in banking after the crisis. CGFS Papers, No 60, Bank for International Settlements. https://www.bis.org/publ/cgfs60.pdf. Downloaded: 5 October 2020.

BIS (2020): Payment aspects of financial inclusion in the fintech era. Committee on Payments and Market Infrastructures - World Bank Group (CPMI-WBG), Bank for International Settlements, April. https://www.bis.org/cpmi/publ/d191.pdf. Downloaded: 4 June 2020.

Dahdal, A. - Barberis, J. - Walker, G. - Truby, J.M. - Arner, D. (2020): Payments \& InsurTech in times of COVID-19. https://cfte.education/2020/03/20/payments-insurtech-in-timesof-covid-19/. Downloaded: 5 June 2020. 
Digitális Jólét Nonprofit Kft. (2019): Magyarország Fintech Stratégiája. A hazai pénzügyi szektor digitalizációja 2019-2022 (Hungary's Fintech Strategy. Digitalisation of the domestic financial sector 2019-2022). Digitális Jólét Nonprofit Kft. Hillbrown Consulting Kft. http://digitalisjoletprogram.hu/api/v1/companies/15/files/120886/download. Downloaded: 7 June 2020.

EBA (2020): Report on big data and advanced analytics. European Banking Authority. https://www.eba.europa.eu/sites/default/documents/files/document_library//Final\%20 Report\%20on\%20Big\%20Data\%20and\%20Advanced\%20Analytics.pdf. Downloaded: 5 June 2020.

EC (2020a): A European strategy for data. European Commission. https://ec.europa.eu/info/ sites/info/files/communication-european-strategy-data-19feb2020_en.pdf. Downloaded: 5 June 2020.

EC (2020b): White Paper on Artificial Intelligence - A European Approach to Excellence and Trust. European Commission. https://ec.europa.eu/info/sites/info/files/commission-whitepaper-artificial-intelligence-feb2020_en.pdf. Downloaded: 5 June 2020.

EP (2020): Draft report with recommendations to the Commission on the Digital Services Act: Improving the functioning of the Single Market. European Parliament. https://www. europarl.europa.eu/doceo/document/IMCO-PR-648474_EN.pdf. Downloaded: 6 October 2020.

FSI (2020): Policy responses to fintech: a cross-country overview. FSI Insights on policy implementation, No 23, Financial Stability Institute. https://www.bis.org/fsi/publ/ insights23.pdf. Downloaded: 4 June 2020.

Hungarian Fintech Association (2020): Introduction. https://mafisz.hu/wp-content/ uploads/2020/03/MAFISz-c\%C3\%A9Ikit\%C5\%B1z\%C3\%A9sek-magyar-angol-202003127. pdf. Downloaded: 7 June 2020.

IMF (2018): The Bali Fintech Agenda: A Blueprint for Successfully Harnessing Fintech's Opportunities. IMF Policy Paper, International Monetary Fund, October. https://www. imf.org/en/Publications/Policy-Papers/Issues/2018/10/11/pp101118-bali-fintech-agenda. Downloaded: 5 June 2020.

MNB (2019): Financial innovation and stability. FinTech strategy of the Magyar Nemzeti Bank. https://www.mnb.hu/letoltes/mnb-fintech-strategy-eng-cov.pdf. Downloaded: 4 October 2020.

MNB (2020a): FinTech and Digitalisation Report. Magyar Nemzeti Bank. https://www.mnb. hu/letoltes/fintech-es-digitalizacios-jelente-s-final-eng.pdf. Downloaded: 4 June 2020. 
MNB (2020b): Kockázatok merülhetnek fel egyes határon átnyúló számla- és kártya szolgáltatásoknál (There may be risks with some cross-border account and card services). MNB Release, 24 February, Magyar Nemzeti Bank. http://penzugyifogyaszto. hu/kockazatok-merulhetnek-fel-egyes-hataron-atnyulo-elektronikus-szamla-eskartyaszolgaltatasoknal/. Downloaded: 4 October 2020.

Müller, J. - Kerényi, Á. (2019): The Need for Trust and Ethics in the Digital Age - Sunshine and Shadows in the FinTech World. Financial and Economic Review, 18(4): 5-34. http:// doi.org/10.33893/FER.18.4.534

OECD (2020): Digital Disruption in Banking and its Impact on Competition. http://www.oecd. org/daf/competition/digital-disruption-in-banking-and-its-impact-on-competition-2020. pdf. Downloaded: 7 June 2020.

Philippon, T. (2020): On FinTech and financial inclusion. BIS Working Papers, No 841. https:// www.bis.org/publ/work841.pdf. Downloaded: 4 June 2020.

PWC (2019): Amazonisation is the future of European financial services. PwC and Luxembourg for Finance. https://www.luxembourgforfinance.com/news/amazonisation-is-the-futureof-european-financial-services/

ROFIEG (2019): 30 recommendations on regulation, innovation and finance. Final Report to the European Commission. https://ec.europa.eu/info/sites/info/files/business_economy_ euro/banking_and_finance/documents/191113-report-expert-group-regulatory-obstaclesfinancial-innovation_en.pdf. Downloaded: 5 June 2020. 